\title{
IAMJ
}

INTERNATIONAL

AYURVEDIC

MEDICAL JOURNAL

ISSN: 23205091

Impact Factor: 5.344

\section{THE CONCEPT OF STANYA DUSTI AND ITS ROLE IN THE MANAGEMENT OF EARLY INFANTILE AILMENTS -A CASE STUDY}

\section{Mulla Meenaj ${ }^{1}$, Singh sudha ${ }^{2}$, Thube Satish ${ }^{3}$, Deodas M. S. ${ }^{4}$}

${ }^{1}$ PG Scholar, ${ }^{2}$ Associate Professor, ${ }^{4}$ Professor, Department of Kaumarbhritya, PDEA'S College of Ayurveda And Research Centre, Nigdi, Pune, Maharashtra-44; India

${ }^{3}$ Associate Professor, Prasutitantra \& Strirog, Dr. Rajendra Gode ayurvedic college, Mardi Road, Amravati, Maharashtra, India

Email: mullameenaj91@gmail.com

\section{https://doi.org/10.46607/iamj0807312020}

(Published online: July 2020)

Open Access

(C) International Ayurvedic Medical Journal, India 2020

Article Received: 08/06/2020 - Peer Reviewed: 21/06/2020 - Accepted for Publication: 01/07/2020

Check for updates

\begin{abstract}
Breast milk is the prime source of nourishment to a newborn baby. Breast milk improves the physical as well as mental strength and immunity of the baby. In Ayurveda unique concept of Stanya dusti or milk vitiation has been described in which mother food and activities affect the quality and quantity of milk. If mother indulges in unwholesome diet and lifestyle habits, then the milk gets vitiated and leads to various diseases in her baby. It shows that only treating the symptoms of baby is not enough. So, the treatment of vitiated breast milk is equally important. In Ayurveda certain herbs and formulations are specifically indicated for detoxifying the breast milk and improve the quality of milk and growth of the baby along with liberation of vitiated symptoms.
\end{abstract}

Keywords-Breast milk, Stanydusti, Ayurveda 


\section{INTRODUCTION}

IMPORTANCE OF BREAST MILK: Breast milk is complete food and it provides all the nutrients a baby needs during $1^{\text {st }} 6$ months of life. It has a nearly perfect mix of vitamins, protein, fat everything your baby needs to grow. It is easily digestible due to presence of special enzyme, lipase, and high quality of whey protein. Breast milk contains a number of anti-infective substances, protective antibodies and friendly lactobacilli, which protect the baby against development of diarrhea, respiratory illness, and other infection. There is reduced risk of acute otitis media and necrotizing enterocolitis (NEC) in breastfed babies. ${ }^{1}$ Breast feeding provides immunological benefits to the baby. Breast feed babies have been shown to develop better protective response to various vaccine. Breastfed babies are smarter and have been shown to have 8 points higher intelligence quotient (IQ) and enhance visual development. High concentration of two key long chain fatty acids (Arachidonic acid and DHA) lactose and Salic acid promote brain growth. Breast feed ba- bies are less likely to suffer from caries teeth , type 2 Diabetes mellitus (D.M), obesity ,high blood pressure , heart attacks and certain cancer during adult life. ${ }^{1,2}$ According to Ayurveda ,importance of breast milk has been described by various Acharyas. Term Shudhastanya' has been used for healthy Stanya (breast milk) having properties like Shankhapramane shweta (shell like white or light yellow), Madhur (Sweet in taste), Laghu (easily digestible), Pathykar, Deepan (appetizer), Jeevaniya, Snehan, Bruhaniya, Shareeropchya, Balarudhikar, Pushtikar, Aarogyakar. Breast milk can be used locally in Raktapita (Bleeding disorder), Akshishool (Eye pain), etc. ${ }^{3}$ Eight type of Stanyadusti described in Charaksamhita. The disease caused by Stanya dusti and its management has been described thoroughly in Samhitas. It is unique and practical concept mentioned in Ayurveda because Stanya form inside mother body so qualities of mother milk will be different as per Ahar-vihar of mother.

Table 1: Qualities of Stanya Sampatas As Per Various Acharyas ${ }^{3,4,5,6}$

\begin{tabular}{|c|c|c|c|c|c|c|c|}
\hline Samhita & Guna & Rasa & Gandha & Sparsha & Varipariksha & Karya & Parinama \\
\hline Sushrut & $\begin{array}{l}\text { Shankhapramaneshwata } \\
\text { (Shell like white) }\end{array}$ & $\begin{array}{l}\text { Madhur } \\
\text { (Sweet) }\end{array}$ & - & $\begin{array}{l}\text { Sheeta } \\
\text { (Cold) }\end{array}$ & Ekrupata & $\begin{array}{l}\text { Laghupathyakar } \\
\text { Deepan }\end{array}$ & Shareeropchay \\
\hline Charak & $\begin{array}{l}\text { Prakrutibootvarna, } \\
\text { Gandha, Rasa, Sparsh }\end{array}$ & - & - & - & Ekrupata & $\begin{array}{l}\text { Jeevan, Bruhan, } \\
\text { Snehan, Use in } \\
\text { Raktapitta, } \\
\text { Akshishool }\end{array}$ & $\begin{array}{l}\text { Pushteekar } \\
\text { Arogyakar }\end{array}$ \\
\hline Ashtang Sangraha & - & - & - & - & Ekrupata & $\begin{array}{l}\text { In Raktapitta for } \\
\text { Nasya Akshiroga } \\
\text { for Achchotan } \\
\text { and Tarpan }\end{array}$ & $\begin{array}{l}\text { Arogyakar } \\
\text { Balyajanan }\end{array}$ \\
\hline Ashtangahrudhaya & - & - & - & - & - & - & - \\
\hline KashyapaSamhita & - & - & - & - & - & - & $\begin{array}{l}\text { Avaihata, Bala, } \\
\text { Aayushya, Ni- } \\
\text { rogi, } \\
\text { Sharirvrudhi }\end{array}$ \\
\hline
\end{tabular}

Table 2: Types of Stanya Dusti As Per Various Acharyas ${ }^{3,4,5,7}$

\begin{tabular}{|c|c|c|c|c|}
\hline Samhita & \multirow{2}{*}{$\begin{array}{l}\text { Dosha } \\
\operatorname{Vataj}(3)\end{array}$} & \multicolumn{3}{|l|}{ Types } \\
\hline Charak & & Virasa & Phensanghata & Rukshat \\
\hline \multirow{2}{*}{$\begin{array}{l}\text { Chikitsa } \\
(30 / 238-244)\end{array}$} & Pittaj(2) & Vivarnata & Daurgandhy & \\
\hline & Kaphaj(3) & Atisnigdha & Pichchila & Guruta \\
\hline \multirow[t]{2}{*}{ Harita } & $\operatorname{Vataj}(1)$ & Alpashirata & & \\
\hline & Pittaj(2) & Ushnashirata & Amlashirata & \\
\hline
\end{tabular}




\begin{tabular}{|l|l|l|l|l|}
\hline \multirow{2}{*}{ (54/1-2) } & Kaphaj(2) & Ghanashirata & Ksharshirata & \\
\hline & Vataj & ----- & --- & ----- \\
\cline { 2 - 5 } & Pittaj & ----- & ---- & ----- \\
\cline { 2 - 5 } & Kaphaj & ----- & ---- & ----- \\
\cline { 2 - 5 } & Sannipataj & ----- & ---- & ----- \\
\hline
\end{tabular}

Table 3: Diseases Caused by Various Stanyadusti As Charak Samhita ${ }^{3}$

\begin{tabular}{|c|c|c|}
\hline Dosha & Type of Stanyadusti & Diseases caused by Dusti \\
\hline \multirow[t]{3}{*}{ Vataj } & Virasta & Durbalata (weakness), Vrudhi (Growth) \\
\hline & Phensenghata & $\begin{array}{l}\text { Swarakshinata (Low pitch of voice), Mala-Mutra-Vaayu-Avarodh (Obstruc- } \\
\text { tion in urine and stool), Shirashul (Headache), Peenas (Cold). }\end{array}$ \\
\hline & Rukshata & Balahani (Weakness) \\
\hline \multirow[t]{2}{*}{ Pittaj } & Vaivarnya & $\begin{array}{l}\text { Swedaadhikya (Sweeting), Trushna (Thirst), Dravamalapravrutti (Loose } \\
\text { stool), Shareerasparshushna (Hot to touch). }\end{array}$ \\
\hline & Durgandh & Pandu (Anemia), kamala (Jaundice) \\
\hline \multirow[t]{3}{*}{ Kaphaj } & Snigdha & $\begin{array}{l}\text { Chhardi (Vomiting), Lalasrav (Salivation), } \\
\text { Kasa (Cough), Swasa (Breathless), Tamakswasa (Asthma) }\end{array}$ \\
\hline & Pichhil & Lalasrav (Salivation), Mukha, Netrapradeshishotha (Peri -orbital swelling) \\
\hline & Guru & Hrudhrog (Heart disease) \\
\hline
\end{tabular}

Table 4: Diseases Caused By Various Stanyadusti As Other Samhitas-5,7,8

\begin{tabular}{|l|l|l|}
\hline Samhita & Stanyadusti & Disease \\
\hline Harita & Ghanashira & Utphullika \\
\hline Ashtang-sangrha(U.T2/17) & Tridhoshadusta & Ksheeralasaka \\
\hline Kashyap & Katu,Tikta Rasa & ShakuniGraha \\
\hline & SannipataDosha 19$)$ & Skandha ,Shashtigraha \\
\cline { 2 - 3 } & Swadu,katu Rasa & PutanaGraha \\
\hline
\end{tabular}

Table 5: As per kashyapstanya rasa/varna predominance and its effect- ${ }^{5}$

\begin{tabular}{|l|l|l|}
\hline Sr.no & StanyaRasa/Varna predominance & Its manifestation /effect \\
\hline 1 & Swadhu Rasa & Bahuvinmutrata(Excessive urine and stool) \\
\hline 2 & Kashay Rasa & Mutravingraha(Constipation) \\
\hline 3 & Tailavarna & Balvan (brave) \\
\hline 4 & Ghritavarna & Mahadhani (prosperous) \\
\hline 5 & Dhumvarna & Yashashwi (famous) \\
\hline
\end{tabular}

\section{Stanyadusti Chikitsa-}

Table 6: Stanyadoshachikitsa- ${ }^{3}$

\begin{tabular}{|l|l|l|}
\hline Sr no. & Procedure & Chikitsa \\
\hline 1 & Vamana (purification through oral route) & Vachadikwath \\
\cline { 3 - 3 } & & Nimbadikwath \\
\hline 2 & Virechana (purification through anal route) & Triphaladi yoga \\
\hline
\end{tabular}


Table 7: Visheshchikitsa as per Dosha for Dhatri/mother- ${ }^{3}$

\begin{tabular}{|l|l|l|}
\hline 1 & Vataj & Dashamoolkwath \\
\hline 2 & Pittaj & Amruta, Sariva, Chandan, $k w a t h$ \\
\hline 3 & Kaphaj & Vacha, Sarshap, Pimpalikwath \\
\hline
\end{tabular}

Table 8: Specific Stanyashodhak yoga- ${ }^{3}$

\begin{tabular}{|l|l|l|}
\hline Sr no & Type of Dusti & Specific Kalp \\
\hline 1 & Virassthanyachikitsa & Panchakoladilepa \\
\hline 2 & Fensanghatchikitsa & KirattiktadiKwath, Yavagodhumadilepa \\
\hline 3 & Rukshasthanychikitsa & Panchamoollepa \\
\hline 4 & Vivarnasthanychikitsa & Drakshadilepa \\
\hline 5 & Durgandisthanychikitsa & Abhayadilapa,Sarivadilapa,Pattradilepa \\
\hline 6 & Snighasthanychikitsa & Saindhav,Devdar,Mustha,Patha Kalka \\
\hline 7 & Pichhilsthanychikitsa & TakraaristaPrayog \\
\hline 8 & Gurusthanychikitsa & Guduchi,Nimba,Pattol,TriphalaKwath \\
\hline
\end{tabular}

\section{Case Report}

A- 3-month female infant came to our O.P.D. having complaint of frequent regurgitation of feed5-6per day with sour smell and watery motion 9-10 times per day after late neonatal age. Baby has other symptoms like irritability, excessive thirst. In her feeding history she was on exclusive breast milk and not satisfying with her mother's milk and demanded hourly even after sufficient lactation and dripping of mother milk during feeding. She was achieving minimum normal weight gain for age. Her motor milestones were normal for age. She was the first baby of her parents (non- consanguineous) having history of primary infertility since 12 years and her mother was conceived on her third IVF (in vitro fertilization) procedure and she was on hormonal medication along with regular supplements throughout pregnancy. The baby was full-term
LSCS delivery with birth weight $3.5 \mathrm{~kg}$ and cry at birth. She has not diagnosed as any metabolic disorder or milk intolerance by renowned pediatricians.

They were prescribed various types oflacto-bacillus supplements along with zinc supplements and carminative syrups along with antiemetic syrups for 2 months, but she has gotten no complete relief from above treatment only her motion frequency reduced by 9-10 to 6-7 times per day.

They came for Ayurvedic treatment. After taking the history of baby and mother Stanyadusti has been be considered first and as per mother's symptoms like burning eyes, anorexia, less sleep during night Pittajstanyadusti has been diagnosed. Few herbs of Stanyashodhangana has been prescribed to her mother along with some medication to baby. These are as follows-( Table No.9)

\section{Medication to mother}

Guduchighanvati 1 tab(250mg) twice in a day after meal for 10days

Shatavarighanvati $1 \mathrm{tab}(250 \mathrm{mg})$ thrice in a day with 1 cup milk for 10 days

\section{Medication to baby}

Shati (Kapoorkachri)churna+Jaharmohrapisti + Prawalpisti each 30 $\mathrm{mg}$ three times before milk with honey for 10 days

Continue lactobacillus as prescribed twice in a day for total 7 days
On first follow-up after 10 days the frequency of motion reduced to 3-4 times /day with improve consistency (pasty) and no posseting in baby along with improvement in sleep, feeding satisfaction, and de- crease in irritability. The improvement was very encouraging, and the mother was also feeling better and her sleep hours improved along with feeling of burning eyes symptom relieved. Same treatment has been 
advised to continue for next 10days in baby and mother. On second follow-up motion was normal in consistency, yellow in color and 2-3/day. There was rarely posseting in last week with improvement in sleep pattern and baby was playful. Then advised to stop the medication of baby and continue the medicines in mother for next 10 days then advised to discontinue.

\section{Case Report 2}

A 3.5 months old male baby ( $w t=5.5 \mathrm{~kg}$ ) came to our OPD having perinatal history of full term LSCS with birth weight $3.2 \mathrm{~kg}$ first birth order of mother having pregnancy induced hypertension. His parents were having non consanguineous marriage and having no known systemic disorder. The complaint of baby as per his informant (mother) -Irregular bowel pattern motion (frequency once/5-7 days hard in consistency), excessive crying in lying down (supine position) throughout day and decrease crying after giving car- minatives and at upright position in mother lap or prone position showing infantile colic.

The baby was initially on breast milk +formula milk 2 ounces 3 times /day up to 1 months after that he was exclusively on breast milk. His mother was complaining that her lactation is reduced now, and baby's feed demand increased at every hour. Mother was in stress so less sleeping hours during day and night .She was complaining anorexia, constipation and body ache since last 20 days and she have started chilly and spices in her food since last 20-25 days . The baby was on Lactase enzyme drop $(0.5 \mathrm{ml} 2$ times/day $)$ with carminative drops ( $1.5 \mathrm{ml}$ three times/day) with frequent use of glycerin suppository after every 3days when the baby was uneasy and straining at motion and reduced feeding.

Considering Vatajstanyadusti with association of Pitta his mother was advised to diet modification to reduce spicy food and increase ghee in her diet along with following medication. (Table 10)

\section{Mothers medication}

Dashmoolarista $20 \mathrm{ml}+$ Jeerakadyarista $20 \mathrm{ml}+$ equal water before food two times in a day for 7 days

Guduchighanvati 1-1 tablet twice in a day for 7 days

\section{Baby's medication}

Carmicide drop $1.5 \mathrm{ml}$ thrice in a day as advised for next 7 days
On first follow up the baby was having bowel motion 2 times in a week (after 3 days) without use of suppository, with reduced irritability and colic episodes and mother's appetite increased and constipation was also reduced along with improvement in sleep and body ache. Her lactation was improved than before. Same medication advised for next 15 days for baby as well as mother and after that on second follow-up the bowel frequency of baby was at one day gap with soft in consistency spontaneously along with rarely colic episodes with improved sleep and normal feed demand. His mother was also having improvement in her appetite and bowel habit was normal and body ache much reduced. She was looking fresh and energetic with improvement in lactation. Mother was advised to continue Dashmoolarista and Jeerakadyarista for next 1 month.

\section{DISCUSSION}

In both cases after addition of breast milk purifying herbs, better result came in both babies along with minimum medication to baby than previous allopathic medication. The Ayurvedic medication prescribed to mother in the case $1^{\text {st }}$ was $\mathrm{G} u d u c h i^{10}$ ghanvati and Shatavari ${ }^{10}$ ghan vati both are Tikta rasa herbs having properties like Stanyashodhan, Stanyajanana, Vatapiitahar, Balya, Deepan, Pachana and Rasayana. The baby was prescribed Jaharmohra pisti (having Chardiatisarahar, Sheetavirya and Balya for Annavahashrotas properties), Prawalpisti ${ }^{9}$ (having Chhardihar, Deepan, Pachankaphapittahar, Sheetavirya properties) and Shati/Kapoor kachri ${ }^{10}$ (having Vatanulomak, Chhardihar, Deepan properties) Churna. In $2^{\text {nd }}$ case the mother was prescribed Dashmoolarista $^{9}$ and Jeerakadyarista ${ }^{9}$ along with Guduchi ${ }^{10}$ Ghanvati. Here both Aristas possess prop- 
erties like Deepanapachan and Balya on gastrointestinal system. Both are indicated in Sutikarog. Dashmoolarista is indicated in Dhatukshayavastha and Jeerakarista having Stanyajanana and Dahashamak properties. The medication given to baby was Carmicide drops having an herbal content dill water useful for flatulence and colic pain.

In both cases very encouraging results obtained after consideration of Stanyadusti and adding Stanyasodhan and Stanyajananadravya to mother. We can say for any Vyadhi in Kheerapavastha of baby medication of mother should be taken into consideration especially Stanyadusti concept. This is very practical and unique concept explained by our Acharyas and mentioned that only Dhatri chikitsa is sufficient in many Ksheerapshishuvyadhis.

\section{CONCLUSION}

Breast milk is like an elixir for the baby and it is very important for proper growth and development of baby. It prevents infection and reduce mortality rate in newborn and infants. Hence it is very essential to maintain the quality and consistency of breast milk with various Ayurvedic recipes mentioned in our texts. Any kind of the vitiation in breast milk can affect the health of child. Hence infants on exclusive breast milk or Kheerapshishu should be carefully examined and treated along with consideration of Stanyadusti as described by Acharyas along with proper treatment.

\section{REFERENCES}

1. Meharban Singh, Care of the Newborn ,8th Edition, published by Satish jain, CBC publishers and Distributors Ltd. New Delhi ,110 002, India 2017.

2. Essential Paediatrics - O. P. Ghai, Vind K Paul, 7th Edition, published by L. B. S Publishers \& Distributers Ltd. New Delhi, 110002 India 2009.

3. Tripathi B- Charak Samhita: Volume -2. Varanas Chaukhamba Surbharati Prakashan; 2011 ch.chi 30/697- 699 .

4. Shushruta Samhita, Varanasi; Chaukhamba Prakashan; 2001 shu.sharir 10/31.

5. Kashyapa Samhita, Chaukhambha. SanskritSansthan, Varanasi; 2016 ksSutra 9/9-10.
6. Gupta K. Ashtang Sangraha: Varanasi: Chaukhamba Bharati Acedemy; 2005 (AS. U. T 2/17).

7. Gupta Kaviraj A., Astang Hridaya; Chaukhamba Prakashan; Uttar Tantra 2/1-19;2016

8. Herita Samhita Trutiyasthan (54 / 1-2).

9. Swami krishnanand, Rasatantrasara \& Siddhaprayogsamgrah I part; published by krishnagopal Ayurveda, Ajmer, 2013, page 94,102,367,379

10. Shri Bramhasankar Mishra, Bhavaprakash part I, Chaukhambha. Sanskrit Sansthan, Varanasi, 2002, page $247,269,392$.

\section{Source of Support: Nil \\ Conflict of Interest: None Declared}

How to cite this URL: Mulla Meenaj et al: The Concept Of Stanya Dusti And Its Role In The Management Of Early InFantile Ailments. International Ayurvedic Medical Journal \{online\} 2020 \{cited July, 2020\} Available from: http://www.iamj.in/posts/images/upload/4009 4014.pdf 